I submit, Sir, that an antenatal screening programme of a general population has nothing to recommend it at this time, and that to advocate such a programme in the absence of a full discussion of the relevan issues, some of which I have touched upon here, is little short of irresponsible.-I am, etc.,

J. Philip Welch

Faculty of Medicine,

Department of Paediatrics,

Halifax, N.S., Canada

1 Screening in Medical Care, London, Oxford, University Press (for Nuffield Provincial Hos University Press
pitals Trust), 1968.

2 Welch, J. P. Lancet, 1970, 1, 722

3 Wilson, J. M. G., in Screening in Medical Care p. 97, London, Oxford University Press (for Nuffield Provincial Hospitals Trust), 1968

Gerald, P. S., Pediatrics, 1967, 39, 325

Cunningham, G. C., California Medicine, 1966

Report by the Consultant Paediatricians and Medical Off'cers of Health of the South-east Scot$1968,1,674$.

\title{
Near Drowning
}

SIR,-Three days before the article "Drowning. Its Clinical Sequelae and Management" (18 April, p. 157) appeared, a severe case of near drowning was admitted to the Royal Air Force Hospital Ely. Some points in the management of our case may be of general interest, since despite the high national incidence of actual drowning - up to 1,500 per year-only few of our hospital staff have previously been involved with the treatment of severe near drowning.

The patient, a 7-year-old boy, fell from the bank of a gravel pit. $\mathrm{He}$ was found floating face down by his father who instituted mouth to mouth ventilation and external cardiac massage while his companion ran to alert the emergency ambulance service. Approximately 15 minutes later the patient arrived at the casualty department.

On arrival the patient was unconscious, deeply cyanosed, had inactive dilated pupils, occasional gasning recpiration, and an irregular bradycardia about $40 / \mathrm{min}$. The skin was extremely cold and pale. Shivering and intense muscle spasm, which produced opisthotonos and trismus, were present. Blood pressure was unrecordable. The upper airwav was cleared and the patient ventilated with $100 \%$ oxygen. The suxamethonium used to facilitate intubation made management much easier as opisthotonos stopped. On the assumption that the muscle spasm was due to cerebral oedema resulting from cardiac arrest it was decided to give $100 \mathrm{ml}$ of Urevert intravenously. While this was being given ampicillin $500 \mathrm{mg}$ and cloxacillin $500 \mathrm{mg}$ were given intramuscularly and hydrocortisone $100 \mathrm{mg}$ intravenously. Dextran-40 was given to counteract the profound shock.

The following investigations were then undertaken from femoral arterial puncture. Astrup results 45 minutes after near drowning were:

\section{$\mathrm{pH}$}

Actual $\mathrm{PCO}_{2}$

Base excess

Buffer base

Total $\mathrm{CO}_{2}$
$.0 \mathrm{mEq} / 1$. plasma

6.9

$120 \mathrm{~mm} \mathrm{Hg}$

$-21 \mathrm{mEq} / \mathrm{l}$. blood

$30 \mathrm{mEq} / 1$. blood

$23.0 \mathrm{mEq} / 1$. plasma
$26.6 \mathrm{mEq} / 1$. plasma

(Ventilated on $\left.100 \% \quad \mathrm{O}_{2}\right) \quad \mathrm{Po}_{2} 175 \mathrm{~mm} \mathbf{H g}$ $=99 \cdot 1 \%$ saturated.

Electrolytes: Sodium $114 \mathrm{mEq} / 1$. Potassium $7.4 \mathrm{mEq} / 1$. Chloride $82 \mathrm{mEq} / 1$.

While awaiting these results an infusion of sodium bicarbonate was started and ove the next four hours a total of $250 \mathrm{ml}$ of $4 \cdot 2 \%$ sodium bicarbonate and $350 \mathrm{ml}$ of Ringerlactate together with $500 \mathrm{ml}$ of recta Resonium "A" were given; this achieved correction to:

pH

Actual $\mathrm{PCO}_{2}$

$7 \cdot 22$

Base excess

$105 \mathrm{~mm} \mathrm{Hg}$

Buffer base

$+7 \mathrm{mEq} / 1$. blood

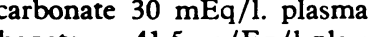

$\quad 41.5 \mathrm{~m} / \mathrm{Eq} / \mathrm{l}$.plasm

Total $\mathrm{CO}_{2}$

$44.6 \mathrm{mEq} / 1$. plasma

During this time the patient became restless and intolerant of his endotrachial tube, which was removed. Diazepam $4 \mathrm{mg}$ intravenously had excellent effect in quietening the patient. Consciousness was regained for the first time six and a half hours after the accident; during this time his mean axillary temperature was $97^{\circ} \mathrm{F}\left(36 \cdot 1^{\circ} \mathrm{C}\right)$.

Chest $x$-ray showed widespread patchy shadowing more marked on the right than left. All urine passed in the first twelve hours was examined for haemoglobin and none found. The following morning, sixteen hours after the accident, the patient ate his normal breakfast and was playing with toys $\mathrm{He}$ was discharged from hospital on the fourth day by which time chest $x$-ray showed considerable improvement in the shadowing.

It is interesting to note the patient's white blood count when seen in the outpatien department five weeks later. Total W.B.C.'s $8300 / \mathrm{mm}^{3}$ with $16 \%$ polymorph and $84 \%$ lymphocytes.

A case such as this at an inland hospital may take a casualty department by surprise and calls for enthusiastic resuscitation by a team, which in our case included surgeon, anaesthetist, and physician.-We are, etc.,

\section{Evans \\ C. PARSONS \\ J. HUNTON}

Royal Air Force Hospital

E!y, Cambs

\section{Clonidine in Treatment of Hypertension}

SIR,-We would like to comment on the work of Dr. A. I. Macdougall and others (22 August, p. 440) and that of Dr. A Amery and others (14 November, p. 392) and to compare it with our work on clonidine. Since our preliminary communication $^{1}$ a detailed report has been published. ${ }^{2}$ Our work on methyldopa and clonidine extended over a period of six months each, and we were able to study in 30 patients the side-effects, effectiveness, and tolerance of the two drugs. Unlike the experience with clonidine of Dr. Macdougall and colleagues who found that "side-effects from the drug were not disabling and were often transient" two of our patients developed such marked drowsiness that they refused to continue with clonidine. We feel that the greater number of side-effeats from clonidine compared with methyldopa which has been observed by Dr. Amery and colleagues and by us, should make the clinician prefer methyldopa to clonidine, as one of the main factors dissuading a hypertensive patient from continuing with his therapy is unwanted side-effects. Tolerance occurred in six of our patients on methyldopa and in seven patients on clonidine. Our average dosage was $916 \mathrm{mg}$ daily of methyldopa and $0.86 \mathrm{mg}$ daily of clonidine.

It seems a pity that Dr. Amery and colleagues used chlorthalidone in combination with both clonidine and methyldopa, as thiazides themselves may be effective hypotensive agents.-We are, etc.

Y. K. SEEDAT

E. I. VAWDA

S. MITHA

R. RAMASAR

Faculty of Medicine,

University of Natal,

See 'at, Y. K., Vawda, E. I., Mitha, S., and
Ramasar, R., Lancet, 1969, 2, 591.
Seedat, Y. K., Vawda, E. I., Mitha, S., and
Ramasar, R., South African Medical fournal,
1970, 44, 300.

\section{Idiopathic Hypercalciuria}

SIR,-I read with interest the paper by Dr. Peter Adams and others (5 December, p. 582). I should like to know whether the plasma potassium was estimated in the five patients who had a low serum inorganic phosphate during the control period Hypokalaemia may be causally related to hypophosphataemia, ${ }^{1}$ and a fall in plasma phosphate can follow thiazide therapy, in some cases uninfluenced by potassium supplements. ${ }^{2}$

I note that five patients had hypercalcaemia after phosphate deprivation, and a further three after the addition of chlorothiazide. How many, if any, of the initial five hypophosphataemic patients appeared in this hypercalcaemic group?I am, etc.,

ANTHONY J. RICHARDS

Clinical Pharmacology Unit,

Institute of Diseases of the Chest,

1 Anderson, D. C., Peters, T. J., and Stewart, W. K. British Merical fournal 1969 Condon, J. R., and Nassim. R., British Medical

\section{Lactic Acidosis}

SIR, - We have recently seen a patient with biochemical findings similar to those reported by Dr. D. E. Barnardo and others (7 November, p. 348). However, our patient had diabetes mellitus and cirrhosis of the liver, and she was taking phenformin-all of which have been implicated as precipitating factors for lactic acidosis.

A 42-year-old female was admitted to hospital with a one-week history of malaise and 24-hour history of progressive deterioration of conscious level. She had had diabetes mellitus for 18 years, treated recently with 20 units soluble insulin and 20 units P.Z.I. She was also receiving $50 \mathrm{mg}$ phenformin per day because of the unstable nature of hor diabetes. One week prior to admission she had reduced her dose of insulin to six units P.Z.I. and four units of soluble because of hypoglycaemic reactions. She also had a three-year history of hepatosplenomegaly with biopsy cvidence of mild cirrhosis. On 
admission she was hypothermic $\left(93^{\circ} \mathrm{F}, 34^{\circ} \mathrm{C}\right.$, rectal), extremely dehydrated, blood pressure 120 / $80 \mathrm{~mm} \mathrm{Hg}$ and pulse rate $66 /$ minute. She was drowsy and confused. The plasma potassium was $5.2 \mathrm{mEq} / 1$., urea $150 \mathrm{mg} / 100 \mathrm{ml}$, bicarbonate $5 \mathrm{mEq} / \mathrm{l}$. and blood glucose $600 \mathrm{mg} / 100 \mathrm{ml}$. Arterial $\mathrm{Po}_{2}$ was 92 and $\mathrm{PCO}_{2} 13 \mathrm{~mm} \mathrm{Hg}$ with a $\mathrm{pH}$ of less than 6.8. The Ketostix test on undiluted plasma was negative. It was concluded that the patient had lactic acidosis with little or no ketoacidosis.

However, further analyses showed a blood lactate of $11.0 \mathrm{mmol} / 1$. (normal, after an overnight fast, less than $1.0 \mathrm{mmol} / \mathrm{l}$.), pyruvate 0.33 $\mathrm{mmol} / \mathrm{l}$. (normal, less than $0.1 \mathrm{mmol} / \mathrm{l}$.), lactate/ pyruvate ratio 33 (normal, 8-15), 3-hydroxybutyrate $4.8 \mathrm{mmol} / 1$. (normal, less than $0.15 \mathrm{mmol}$ / 1.), acetoacetate $0.30 \mathrm{mmol} / 1$. (normal, less than $0.07 \mathrm{mmol} / \mathrm{l}$.), and 3-hydroxybutyrate/acetoacetate ratio of 16 (normal, 1.5-3). After drawing blood for analyses she was treated with soluble insulin (40 units intravenously and 40 units intramuscularly), intravenous bicarbonate and intravenous saline but 30 minutes later the patient suffered a cardiac arrest and, despite resuscitation, died four hours later.

The raised lactate/pyruvate ratio (an indicator of cytoplasmic NAD/NADH ratio) ${ }^{1}$ and raised 3-hydroxybutyrate/acetoacetate ratio (indicating the hepatic mitochondrial redox state) ${ }^{2}$ in both these patients suggests that a severe degree of hepatic anoxia was present. However it would be unlikely that ketone body production should continue at a significant rate in the presence of severe hepatic anoxia. An alternative explanation for the raised 3-hydroxybutyrate/acetoacetate ratio is that in the presence of rapidly deteriorating hepatic function the ratio of ketone bodies in the blood could be set by the preferential uptake of acetoacetate by peripheral tissues (Hawkins, personal communication). Against the suggestion that intracellular $\mathrm{pH}$ may determine the redox state and thus the ketone body ratio is the finding that in 30 patients with diabetic ketoacidosis the ratio was either normal or only mildly elevated (Williamson, Hockaday and Alberti, unpublished observation). The raised lactate/pyruvate ratio can reflect poor perfusion of peripheral tissues and need not necessarily imply hepatic anoxia. Thus the ketone body ratio is, with the proviso mentioned above, the more specific indicator of hepatic redox state. ${ }^{3}$

It is possibly that when lactic acidosis occurs in diabetic patients it will frequently be accompanied by a raised ketone body concentration although the redox state will not necessarily be altered. We cannot offer an explanation for the combined acidosis and redox disturbance found by Dr. Barnardo and his colleagues beyond suspecting tissue anoxia due to septicaemia, but we feel that many such cases will be revealed as more frequent measurements of blood metabolites are made in susceptible patients.

Finally, we should like to emphasize that the Ketostix test for blood acetoacetate can be negative even when total blood ketone bodies are grossly elevated.

We are grateful to Professor P. B. Beeson for permission to report the details of this case. -We are, etc.,

\section{K. G. M. M. Alberti}

J. Corbett

T. D. R. HOCKADAY D. H. WILliamSON

Nuffield Department of Clinical Medicine, Metabolic Research Laboratory and Division of Medicine,
Radcliffe Infirmary, Oxford

\footnotetext{
1 Hohorst, H. J., Kreutz, F. H., and Bücher, T., Williamson, D. H., Lund, P., and Krebs, H. A.,
Biochemical fournal, 1967, 103, 514. Williamson,
Brosnan, J. T., Krebs, H. A., and W. Brosnan, J. T., Krebs, H. A., and Williamson,
D. H., Biochemical fournal, 1970, 117, 91.
}

SIR,-I have recently estimated the blood levels of lactic acid in 110 patients in an intensive care unit (in press). This work suggested that inadequate perfusion of peripheral tissue was the most important cause of lactic acidosis. In shock, whether this is secondary to cardiac inadequacy or septicaemia, for example, the level of blood lactic acid is raised. When there is no additional disturbance of metabolism, catabolism of lactic acid may take place, especially in the liver. If however other metabolic disturbances such as diabetes, infection, raised blood alcohol levels, etc. are present unrelated independent lactic acidosis can develop. Under these circumstances, therefore, even a slight peripheral production of lactic acid may induce a severe "idiopathic" lactic acidosis, because the breakdown of lactic acid is inadequate. Furthermore, these studies point out that the level of pyruvate in the blood has no clinical significance, either alone or in relation to lactate as lactate-pyruvatequotient.-I am, etc.,

P. V. WICHERT

Department of Medicine,

Hamburg, Germany

\section{Fingerprint Changes in Coeliac Disease}

SIR,-I should like to comment on the interesting paper by Dr. T. J. David and colleagues (5 December, p. 594). Although ridge atrophy may prove to be a diagnostic feature in new cases of adult coeliac disease, after a tentative diagnosis of the latter has been made the cause of associated fingerprint changes should be diagnosed with cautionperhaps until their response to a gluten-free diet has been observed.

The fingerprint changes described, particularly incomplete ridge atrophy and white lines, may on occasions be indistinguishable clinically from those quite commonly seen in dermatitis, including atopic dermatitis, in people with dry hands, and in those whose way of life involves frequent immersion of the hands in water-e.g., housewives. The lowering of ridges seen in dermatitis, housewives, and in some dry hands is reversible. I agree that commonly in dermatitis some fingers may be normal and others affected and that changes of a particular print may be patchy. However, ridge flattening (not usually with complete loss of visible ridges) and white lines of all digits (and often of palms also) may be seen in patients with atopic dermatitis even in the absence of dermatitis involving the fingerprint area.

It is, of course, also well known that skin changes including eczema may be associated with a gluten-sensitive enteropathy, so that one should not be surprised to find eczema present in some cases of coeliac disease. In wasting diseases, generally, ridged skin over finger tips often remains normal (as in the 40 patients mentioned by Dr. David and his colleagues), but it can certainly be dry, flattened, and wrinkled. The high incidence of ridge atrophy found in coeliac disease was clearly not necessarily associated with dry skin, but perhaps some reversible factor interfering with the nutrition of the papillary layer of dermis and epidermis will eventually be found to account for these changes.
The increase in height of skin ridges after treatment with a gluten-free diet is an exciting finding, and will prove of some importance if ridge changes do correlate closely with jejunal mucosal changes. It will also be interesting to see from further studies whether similar fingerprint changes to those described are seen in some patients with tropical sprue, ulcerative colitis, and dermatitis herpetiformis, in which conditions jejunal mucosal changes similar to coeliac disease may be present.-I am, etc.,

JULIAN VERBOV

Department of Dermatology,
St. Bartholomew's Hospital,
London E.C.1

Postoperative Leg Vein Thrombosis

SIR, - When we began our study of the effect of a major surgical operation under general anaesthesia on the rate of the venous return from the lower limbs, we were helped by Mr. L. T. Cotton's earlier investigations on the effect of posture and calf muscle activity on the venous return of conscious patients. Again we are indebted to him and his colleagues (28 November, p. 556) for demonstrating as a fact what we had guessed but not confirmed.

When designing the experiment which showed that during an operation electrical stimulation of the calf prevented the development of venous stasis, which otherwise occurred, we had to decide whether to stimulate the right or left leg in a random series, or always to stimulate the same one. Although there was no proof, rumour said that owing to the compression of the left common iliac vein by the right common iliac artery the venous return from the left lower limb was slower than the right. We therefore chose to always stimulate the left leg because to succeed over an initial disadvantage would strengthen the value of a positive result. We did suceed and our result was the stronger for our choice.

Similarly, when we designed the clinical trial to try and find out if electrical stimulation of the calf reduzed the risk of deep vein thrombosis by reducing the risk of venous stasis in the theatre, we considered what effect the stimulation of one leg might have on the rate of the venous return from the other. As we were postulating that venous stasis dicnosed to deep vein thrombosis, then it followed that, if stimulating one leg accelerated the venous return in the other limb, then by reducing the difference in the rate between the stimulated and the unstimulated limbs it would again make it more difficult to demonstrate that calf stimulation did in fact reduce the risk of deep vein thrombosis. As before, we succeeded. ${ }^{2}$ It is a relief to know that I no longer need worry about the off-chance that stimulating the calf of one limb might reduce the rate of venous return in the other.

As far as the relationship between venous stasis and deep vein thrombosis is concerned, therefore, I need not apologise for using one leg as the control for the other in each patient. To have used both legs so that patients whose limbs were stimulated had to be compared with those in which no stimulation was used at all would have been statistically clumsy and would have 